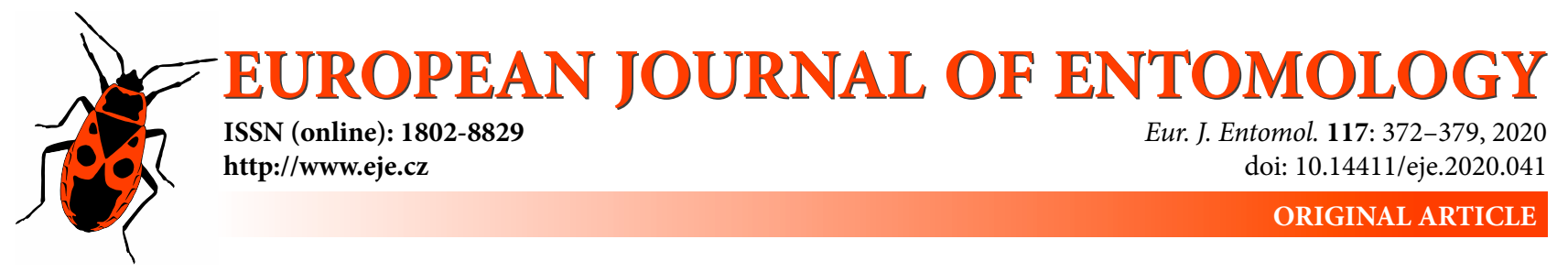

\title{
Influence of forest decline on the abundance and diversity of Raphidioptera and Mecoptera species dwelling in oak canopies
}

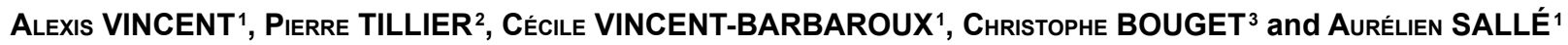 \\ ${ }^{1}$ Laboratoire de Biologie des Ligneux et des Grandes Cultures, INRAE, Université d'Orléans, 45067 Orléans, France; \\ e-mails: alexis.vincent@etu.univ-orleans.fr, cecile.barbaroux@univ-orleans.fr, aurelien.salle@univ-orleans.fr \\ 28 rue d'Aire, F-95660 Champagne-sur-Oise, France; e-mail: p.tillier.entomo@free.fr \\ ${ }^{3}$ INRAE, UR EFNO, Domaine des Barres, Nogent-sur-Vernisson, France; e-mail: christophe.bouget@inrae.fr
}

Key words. Raphidioptera, Mecoptera, forest decline, canopy, intermediate disturbance hypothesis, Quercus

\begin{abstract}
Trees in a state of decline exhibit a reduced foliage density and accumulate dead branches in their crowns. Consequently, forest decline can markedly affect both the habitats and sources of food for canopy-dwelling insects. The decline-induced increase in canopy openness may also modify the understory, shrub and ground layers, and have cascading effects on associated species. Flight interception traps and green Lindgren traps were used to survey the canopy-dwelling insects in stands of healthy and declining oak trees, in particular two insect orders: Raphidioptera, saproxylic insects associated with canopies, and Mecoptera, necrophagous or opportunistic species associated with the herbaceous or shrub strata. Overall, green Lindgren traps caught more of these insects than flight interception traps. The traps caught five species of Raphidioptera. Three of them, Subilla confinis, Phaeostigma major and, to a lesser extent, Phaeostigma notata, were more abundant in stands or plots with declining trees. However, the other two species of Raphidioptera, Atlantoraphidia maculicollis and Xanthostigma xanthostigma exhibited a reverse trend. Two species of Mecoptera, Panorpa germanica and Panorpa communis, were particularly abundant, but unaffected by the level of decline. Our results show that declining forests can either host more or fewer species of Raphidioptera with saproxylic larvae, whereas Mecoptera with ground-living larvae were unaffected. Seasonal phenology and sex ratio of the species are also discussed.
\end{abstract}

\section{INTRODUCTION}

Global change is dramatically affecting forest ecosystems, either by creating novel types or by increasing the frequency and/or intensity of natural disturbances (Liebhold et al., 2017; Seidl et al., 2017). According to the intermediate disturbance hypothesis, while the outcome may be detrimental at extreme levels, disturbance may have positive outcomes on biodiversity at intermediate levels of severity and frequency (Grime, 1973; Connell, 1978). For instance, wind throw gaps or fires can promote insect diversity at the landscape level (Bouget \& Duelli, 2004; Moretti et al., 2004). Nonetheless, the outcome of disturbance and whether the effects on insect diversity are positive or negative, may depend on the taxonomic groups and functional guilds considered (e.g. Moretti et al., 2004; Sallé et al., 2020).

Forest decline consists of a progressive loss of vigour in trees, over several years in response to multiple, successive or concomitant driving factors (Manion, 1981; Sallé et al., 2014). In response to the predicted increase in the frequency and severity of droughts and heat waves, which are major inciting factors of forest decline, the spatial ex- tent and frequency of declines are expected to increase worldwide (Allen et al., 2010; IPCC, 2013). As decline progresses, forest ecosystems undergo dramatic changes in terms of composition, structure and functioning. In particular, there are conspicuous changes in the structure of the canopy that are uncommon in those of healthy trees, such as dead branches and cavities, which increase the structural complexity of the canopy at scale levels of stand, tree and branch (Ishii et al., 2004). However, it may also negatively affect the amount and quality of other critical resources, such as foliage, fruit and seed (Houston, 1981). Such profound structural modifications can modulate microclimates, habitat opportunities, and trophic resources for canopy-dwelling communities. For instance, oak decline can promote saproxylic and generalist leaf-feeding beetles, but have a negative effect on specialist leaf-feeders (Sallé et al., 2020). Decline-induced environmental changes can also shape habitat conditions at understory and ground levels.

Raphidioptera and Mecoptera are two ancient taxonomic orders of insects frequently encountered in moist temperate forests (Byers \& Thornhill, 1983; Aspöck, 2002). Raphidi- 
optera, or snakeflies, have bark- or ground-dwelling larvae, which generally prey on soft-bodied arthropods, eggs or larvae. Adults are also predatory and mostly feed on aphids and other Sternorrhyncha, but also occasionally consume pollen (Aspöck, 2002). Several species preferentially live in the forest mantle or canopy (Duelli et al., 2002). The corticolous larvae of these species forage on the bark or under loosened bark of trunks and branches (Wichmann, 1957). They can also colonize decayed branches and galleries of bark and wood boring species, where they feed on eggs, larvae, nymphs and immature adults of various species, including saproxylic species (Wichmann, 1957; Kenis et al., 2004; Weigelmeier \& Gruppe, 2010). These snakefly larvae can therefore be considered as saproxylic. Mecoptera, or scorpion flies, have soil-dwelling saprophagous larvae (Byers \& Thornhill, 1983). Adults mostly feed on dead soft-bodied arthropods and opportunistically on other substances such as pollen or plant fluids (Byers \& Thornhill, 1983). Although they can be found in the canopies of trees (e.g. Barnard et al., 1983), adult Mecoptera are generally considered to be associated with herbaceous or shrub strata in forest ecosystems (Byers \& Thornhill, 1983; Duelli et al., 2002). Observations conducted in several forest stands following either fire or wind throw events indicate that both Raphidioptera and Mecoptera may benefit from a certain level of disturbance (Duelli et al., 2019).

We hypothesized that oak decline could indirectly favour species of Raphidioptera with saproxylic larvae, as the increased structural complexity in the crown of declining trees will provide a broader range of oviposition sites and larval habitats, and the increased diversity and abundance of saproxylic species more prey for the larvae. In addition, the increased canopy openness can modify the microclimates in tree crowns and the resulting warmer conditions could promote larval development. On the other hand, the reduced amount of foliage could negatively affect the abundance of aphids and consequently have detrimental effects on the adults. Mecoptera are connected to the soil as larvae and herbaceous or shrub layers as adults, and are presumably less dependent on resources in the canopy. However, increased canopy openness in declining stands might favour lower strata of vegetation and their associated communities. Therefore, we hypothesized that decline would have either no or slightly positive effects on Mecoptera, as suggested by Duelli et al. (2019).

To test these hypotheses, we sampled Raphidioptera and Mecoptera communities in the canopy of mature oaks stands in which the incidence of declining trees ranged from zero to severe. This study was conducted within the frame of an ongoing project investigating how oak decline can affect the trophic guilds of canopy-dwelling insects. For this project, we have been using a multi-taxa approach, including several families of Coleoptera, Hemiptera and Diptera belonging to different trophic guilds. Here we specifically report on the results concerning Raphidioptera and Mecoptera. For these two groups, our objectives were to (i) identify the canopy-dwelling species of Raphidioptera and Mecoptera, (ii) evaluate the association between abundance and diversity of these species and the local intensity in forest decline, and (iii) provide additional information on the ecology of these poorly studied groups.

\section{MATERIAL AND METHODS}

\section{Study sites}

This study was conducted in three state forests, located near Orléans (Forêt domaniale d'Orléans, 47 $98^{\prime} 97^{\prime \prime} 81 \mathrm{~N}, 1^{\circ} 95^{\prime} 44^{\prime \prime} \mathrm{E}$ ), Vierzon (Forêt domaniale de Vierzon, $47^{\circ} 26^{\prime} 89^{\prime \prime} \mathrm{N}, 02^{\circ} 10^{\prime} 74^{\prime \prime} \mathrm{E}$ ) and Marcenat (Forêt domaniale de l'Abbaye, 46 ${ }^{\circ} 21^{\prime} 12^{\prime \prime} \mathrm{N}$, $\left.3^{\circ} 36^{\prime} 13^{\prime \prime} \mathrm{E}\right)$. The forest at Orléans covers 35,000 ha and is dominated by oaks $(55 \%)$ and pines $(39 \%)$. The forest at Vierzon, and the adjacent forest at Vouzeron cover a surface area of 7,500 ha and are dominated by oaks $(61 \%)$ and pines $(31 \%)$. Oaks in the forest at Vierzon, in particular $Q$. robur, have regularly suffered

Table 1. Characteristics of the oak stands monitored.

\begin{tabular}{|c|c|c|c|c|c|c|c|}
\hline Forest & $\begin{array}{l}\text { Stand } \\
\text { ID }\end{array}$ & Overstorey & Understorey & $\begin{array}{c}\text { Stand } \\
\text { height }(\mathrm{m})\end{array}$ & $\begin{array}{c}\text { Mean } \pm \text { SE } \\
\text { oak DBH }(\mathrm{cm})\end{array}$ & $\begin{array}{l}\text { Tree density } \\
\text { (n/ha) }\end{array}$ & $\begin{array}{l}\text { Total basal } \\
\text { area }\left(\mathrm{m}^{2} / \mathrm{ha}\right)\end{array}$ \\
\hline Vierzon & $19 C$ & Oak with scattered beech and Scots pine & Hornbeam & 26 & $57 \pm 3$ & 89 & 18 \\
\hline Vierzon & 35 & Oak with scattered beech and Scots pine & & 26 & $54 \pm 3$ & 105 & 21 \\
\hline Vierzon & 70 & Oak with scattered beech and Scots pine & & 24 & $49 \pm 6$ & 58 & 9 \\
\hline Vierzon & 71 & Oak with scattered beech and Scots pine & Beech & 25 & $40 \pm 4$ & 105 & 15 \\
\hline Vierzon & 81 & Oak & Hornbeam & 24 & $43 \pm 2$ & 197 & 15 \\
\hline Vierzon & 179 & Oak & & 29 & $64 \pm 6$ & 81 & 21 \\
\hline Vierzon & 236 & Oak with scattered beech & & 24 & $73 \pm 4$ & 88 & 23 \\
\hline Vierzon & 249 & Oak with scattered beech and hornbeam & & 25 & $52 \pm 2$ & 127 & 22 \\
\hline Vierzon & 290 & Oak & Scattered wild service trees & 23 & $51 \pm 2$ & 160 & 22 \\
\hline Orléans & 351 & Oak with scattered Scots pine & Chestnut and wild service trees & 24 & $63 \pm 5$ & 136 & 18 \\
\hline Orléans & 751 & $\begin{array}{l}\text { Mixed stand of oak and beech, } \\
\text { with scattered Scots pine }\end{array}$ & Hornbeam & 27 & $64 \pm 4$ & 107 & 24 \\
\hline Orléans & 1140 & Oak & Scattered glossy buckthorn & 25 & $72 \pm 6$ & 90 & 26 \\
\hline Orléans & 1343 & Oak & & 28 & $75 \pm 4$ & 100 & 28 \\
\hline Orléans & 1344 & Oak & & 24 & $78 \pm 5$ & 74 & 27 \\
\hline Orléans & 1427 & Oak & & 26 & NA & 140 & 15 \\
\hline Orléans & 1490 & Oak and scattered aspen & Hornbeam & 23 & $70 \pm 9$ & 73 & 17 \\
\hline Orléans & 1491 & Oak and scattered aspen & Hornbeam & 23 & $65 \pm 3$ & 90 & 17 \\
\hline Orléans & 1502 & Oak and scattered aspen & Hornbeam & 21 & $48 \pm 3$ & 222 & 16 \\
\hline Marcenat & t 12 & Oak & Hornbeam & 29 & $56 \pm 6$ & 154 & 19 \\
\hline Marcenat & 37 & Oak & Hornbeam and linden & 37 & $79 \pm 4$ & 76 & 18 \\
\hline Marcenat & 58 & Oak & Scattered hornbeam & 23 & $40 \pm 4$ & 389 & 33 \\
\hline
\end{tabular}


from decline (Sallé et al., 2020). The forest at Marcenat covers 2,100 ha, and is largely dominated by oaks $(71 \%)$ with some pines $(11 \%)$ and Douglas fir $(8 \%)$. Several stands are currently experiencing decline, triggered by recurrent summer droughts (Baubet O., Département de la Santé des Forêts, pers. comm.).

We selected 21 mature oak-dominated stands (minimal surface area: $3 \mathrm{ha}$ ): nine in the forest of Orléans, nine in the forest of Vierzon and three in the forest of Marcenat. Stands were located at least $500 \mathrm{~m}$ from one another. Within each stand, two trees were selected, one healthy and one declining (if both tree types were present) at least $50 \mathrm{~m}$ apart. Traps were placed in these trees (see sampling protocols).

In each stand we recorded average tree height, diameter and density, as well as stand composition (Table 1). We also evaluated the level of decline at three embedded spatial scales: (i) trees with a trap, hereafter referred to as the tree scale, (ii) the ten closest oaks surrounding the trees with traps, hereafter referred as a plot, and (iii) 30 trees in the stand (i.e. the 20 trees in the two monitored plots and 10 trees in an additional plot located between the two monitored plots), hereafter referred as a stand (Table 2). We evaluated the decline level of each tree using the DEPERIS protocol developed by the French Forest Health Department (Département de la Santé des Forêts) (Goudet \& Nageleisen, 2019). In summary, percentage of dead branches and ramification loss in the canopy were evaluated. Based on these criteria, each tree was assigned to a class of decline ranging from $\mathrm{A}$ (no decline) to $\mathrm{F}$ (severe decline). Trees belonging to $\mathrm{A}-\mathrm{C}$ classes were considered healthy. Trees belonging to D-F classes were considered in decline. At plot and stand scales, the percentage of declining trees (falling within D-F classes) was calculated (Table 2).

\section{Sampling}

Insects were collected using green multi-funnel traps (GMFT) (Lindgren traps, Chemtica Internacional, San Jose, Costa Rica), each with 12 fluon-coated funnels, and cross-vane flight interception traps (FIT) $\left(\right.$ Polytraps $\left.^{\mathrm{TM}}\right)$. Both types of traps were suspended approximately $15 \mathrm{~m}$ above the ground (i.e. among the lower branches in the canopy), in the same tree. The collectors were

Table 2. Decline indices of trees bearing traps and percentage of surrounding declining trees in the monitored oak plots and stands

\begin{tabular}{|c|c|c|c|c|c|c|}
\hline \multirow[t]{2}{*}{ Forest } & \multirow[t]{2}{*}{$\begin{array}{l}\text { Stand } \\
\text { ID }\end{array}$} & \multicolumn{2}{|c|}{$\begin{array}{l}\text { Decline index } \\
\text { of trees with } \\
\text { traps }\end{array}$} & \multicolumn{2}{|c|}{$\begin{array}{l}\text { Percentage of } \\
\text { declining trees } \\
\text { at the plot scale }\end{array}$} & \multirow{2}{*}{$\begin{array}{l}\text { Percentage } \\
\text { of declining } \\
\text { trees at the } \\
\text { stand scale }\end{array}$} \\
\hline & & $\overline{T r e e ~ \# ~}$ & ee \#2 & Plot \#1 & Plot \#2 & \\
\hline Vierzon & 19 & $\mathrm{C}$ & $\mathrm{D}$ & 100 & 80 & 93 \\
\hline Vierzon & 35 & B & C & 20 & 80 & 43 \\
\hline Vierzon & 70 & C & D & 50 & 100 & 73 \\
\hline Vierzon & 71 & B & $E$ & 40 & 90 & 63 \\
\hline Vierzon & 81 & C & D & 5 & 50 & 18 \\
\hline Vierzon & 179 & C & $\mathrm{D}$ & 55 & 50 & 63 \\
\hline Vierzon & 236 & D & $\mathrm{E}$ & 80 & 35 & 45 \\
\hline Vierzon & 249 & $E$ & $\mathrm{~F}$ & 80 & 30 & 35 \\
\hline Vierzon & 290 & C & D & 15 & 50 & 28 \\
\hline Orléans & 351 & C & D & 0 & 10 & 3 \\
\hline Orléans & 751 & C & D & 50 & 20 & 33 \\
\hline Orléans & 1140 & D & $E$ & 60 & 60 & 63 \\
\hline Orléans & 1343 & B & $B$ & 0 & 10 & 3 \\
\hline Orléans & 1344 & D & $E$ & 30 & 70 & 47 \\
\hline Orléans & 1427 & C & $E$ & 20 & 60 & 37 \\
\hline Orléans & 1490 & B & C & 20 & 10 & 30 \\
\hline Orléans & 1491 & B & $\mathrm{C}$ & 0 & 20 & 30 \\
\hline Orléans & 1502 & B & $\mathrm{D}$ & 10 & 40 & 23 \\
\hline Marcenat & 12 & D & $D$ & 60 & 60 & 55 \\
\hline Marcenat & 37 & C & C & 10 & 0 & 30 \\
\hline Marcenat & 58 & C & C & 0 & 60 & 47 \\
\hline
\end{tabular}

filled with a solution of $50 \%(\mathrm{v} / \mathrm{v})$ monopropylene glycol and water plus a drop of detergent. The traps were set from the end of March to the beginning of September 2019. The collectors were emptied every month and the species caught recorded.

\section{Identification}

Most of the specimens were identified by AV and validated by PT. We used the Mecoptera identification key of Tillier (2006) and unpublished key of B. Bal and P. Tillier for the Raphidioptera, which is a modified version of the key of Semeria and Berland (1988). The sex ratio (males/females) was calculated for each species. For both Raphidioptera and Mecoptera, we recorded the number of individuals (abundance) and for Raphidioptera the number of species (richness) at the tree scale.

\section{Data analysis}

All analyses were performed in R, version 3.5.1 (R Core Team 2018). To assess the effect of trap type on the insects sampled, we performed Wilcoxon signed-ranked tests. Spearman correlation tests were used to study the abundance of species at the tree level. To rank the effect of the level of decline at tree, plot or stand scales on variations in average univariate metrics (mean values of abundance of each species per trap, taxonomical order abundance, group species richness), we used the differences in the Akaike information criterion (AICc) scores to compare the fit between the generalized linear mixed models including each of the three explanatory variables separately. To assess the significance of the estimates of the best decline feature for each response variable, the error structure of the generalized linear mixed-effects models was adjusted to better fit the data. In order to do so, glmm were fitted for negative binomial, Gaussian, log-normal and Poisson family (functions lmer, glmer.nb and glmer, lme4 R-package). Since both types of traps were present in the same tree, two trees within the same stand had traps and some stands were in the same forest, we added forest, stand and tree as nested random factors to our mixed model. We also added trap type as a fixed effect. To plot the predictions of generalized linear mixed-effects models based on abundance per tree (i.e. with catches of GMFT and FIT pooled), we used the ggpredict() function in the ggeffects package.

\section{RESULTS}

Totals of 5374 Mecoptera and 572 Raphidioptera were caught. All Mecoptera were either Panorpa germanica L. (3072 ind.) or Panorpa communis L. (2302 ind.). Panorpa germanica was more abundant than $P$. communis at Marcenat and Orléans, while $P$. communis dominated at Vierzon.

Five species of Raphidioptera were collected of which the most abundant in the three forests was Subilla confinis (Stephens) (310 ind.), followed by Phaeostigma major (Burmeister) (95 ind.), Phaeostigma notata (Fabricius) (66 ind.), Atlantoraphidia maculicollis (Stephens) (54 ind.) and Xanthostigma xanthostigma (Schummel) (47 ind.). Neither $P$. notata nor $A$. maculicollis were caught at Marcenat.

\section{Sex ratio}

For both species of Mecoptera their sex ratio was slightly skewed towards female ( 0.79 and 0.68 for $P$. communis and $P$. germanica, respectively). In contrast, the sex ratio of the species of Raphidioptera caught was consistently and sometimes markedly skewed towards male (X. xanthostigma: 1.19, A. maculicollis: $1.32, P$ major: 2.13, P. notata: 2.73, S. confinis: 3.03 ). 

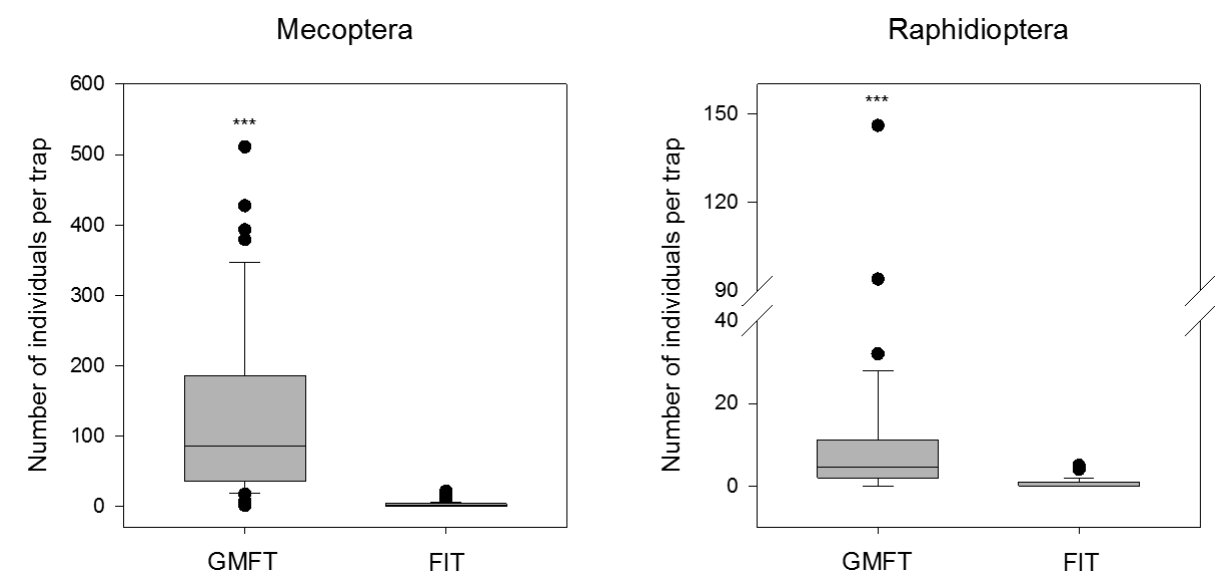

Fig. 1. Boxplots of the number of Mecoptera (left) and Raphidioptera (right) caught by green multi-funnel traps (GMFT) and flight interception traps (FIT) in oak canopies.

\section{Effect of trap type}

For all species, many more individuals were caught in green multi-funnel traps than in flight interception traps $(\mathrm{P}$ $<0.01$ for all species Fig. 1).

\section{Seasonal activity}

For the analysis of seasonal activity, catches of both types of trap were pooled. The two species of Mecoptera differed markedly in their seasonal activity (Fig. 2). While most individuals of $P$. communis were caught in June, two peaks of activity were recorded for $P$. germanica, one in May and the other in August. For Raphidioptera, P. major, $P$. notata and $S$. confinis were mostly caught in May and A. maculicollis and X. xanthostigma mostly in April. For most species of Mecoptera and Raphidioptera the seasonal activity of the males and females was similar except for A. maculicollis, where males were more abundant in April ( $80 \%$ of individuals) and females more abundant in May (64\% of individuals).

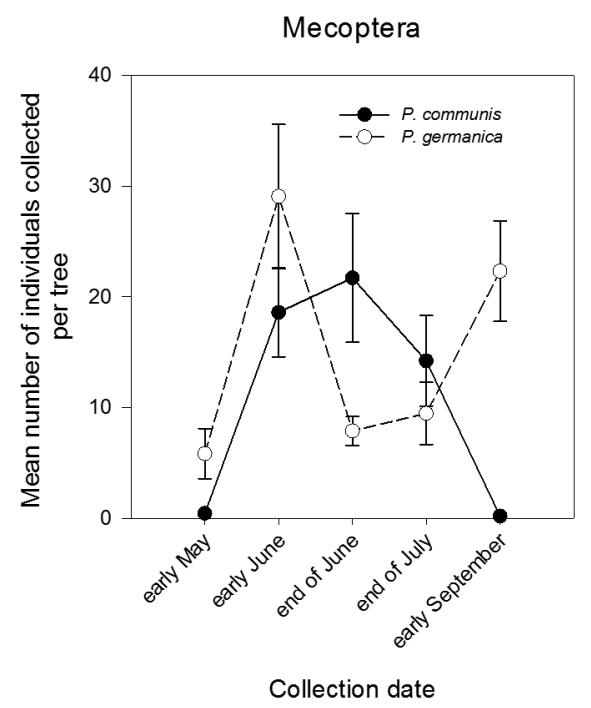

\section{Site-related variations}

Both species of Mecoptera were caught in most of the trees and stands monitored. The abundances of the two species were significantly and positively correlated $(\mathrm{rho}=$ $0.81, \mathrm{P}<0.001)$.

Species of Raphidioptera were more unevenly distributed (Fig. 1, Table S1). Half of the GMFT caught less than 5 individuals and five no specimens. Conversely, several traps caught large numbers of individuals (e.g. 146, 94, 32, 28 and 28). Species frequently co-occurred, and eight traps collected four different species. Abundances of S. confinis, P. major and P. notata were positively correlated (rho $>$ $0.33, \mathrm{P}<0.002$ ).

\section{Effects of decline on diversity metrics}

The abundance of Mecoptera was not associated with the level of decline at any of the three spatial scales considered (Table 3). On the other hand, the abundance of Raphidioptera in general was positively associated with the level of decline, even though abundances recorded at high lev-

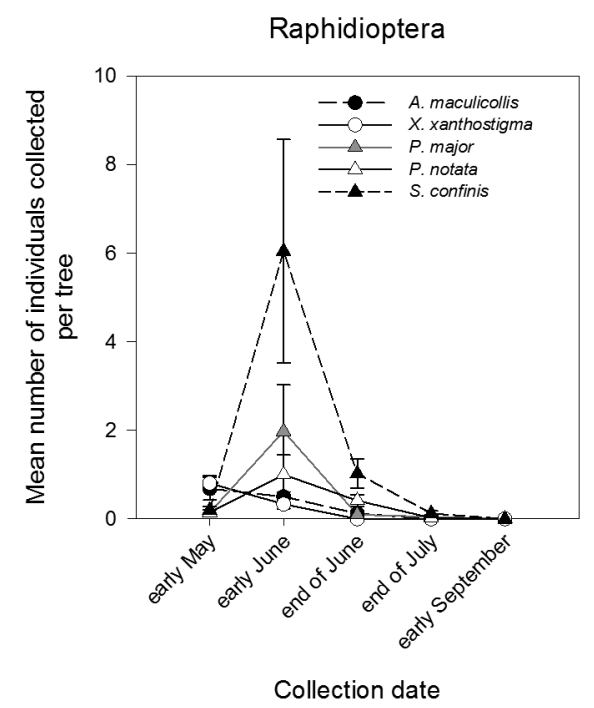

Fig. 2. Seasonal variations in mean ( \pm SE) number of species of Mecoptera (left) and Raphidioptera (right) caught both green multi-funnel traps and flight interception traps (pooled data) suspended in oak canopies. 

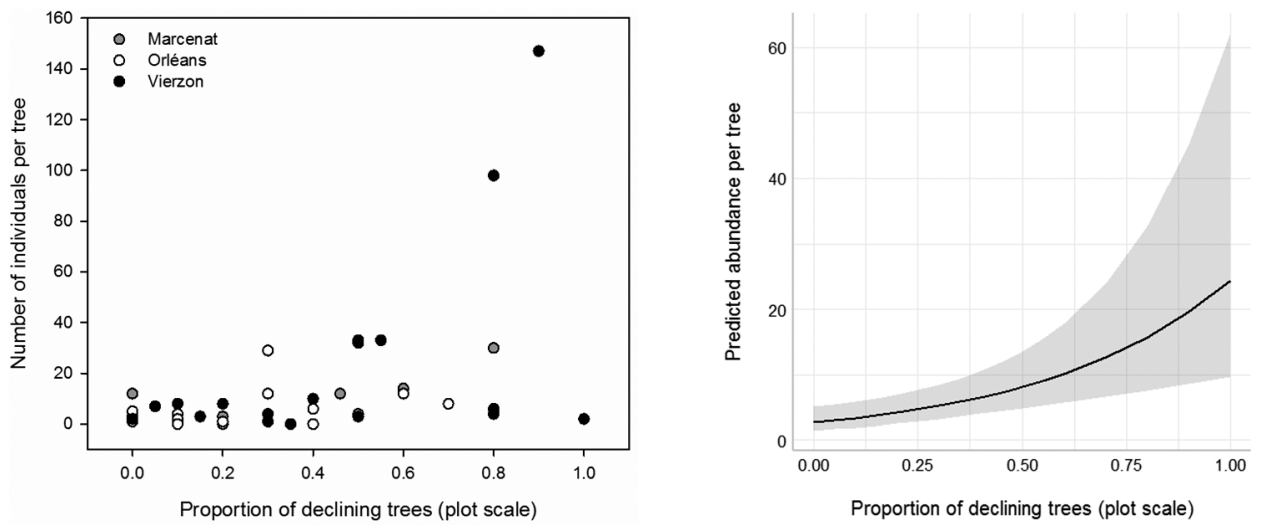

Fig. 3. Relationship between the number of Raphidioptera caught by both green multi-funnel traps and flight interception traps in the same trees, and the percentage of declining trees in the plot (10 trees) surrounding the trap-bearing tree. Left: actual data, right: model prediction and confidence interval (see material and methods).

els of decline were very variable (Table 3, Fig. 3). Abundance increased approximately nine-fold over the gradient in level of decline at the plot scale (Fig. 3). Although not very diverse, the mean local species richness of Raphidioptera also increased with the level of decline at the stand scale (Table 2). At the species level, significant increases in abundance were detected at the plot scale for both $S$. confinis and P. major, and a similar trend was recorded at the stand scale for $P$. notata. Nonetheless, A. maculicollis and $X$. xanthostigma tended to be more abundantly caught on healthy trees than on those in decline.

\section{DISCUSSION}

Large numbers of Mecoptera were caught by the GMFTs placed in the canopies of trees. Panorpa germanica and $P$. communis are very common species and frequently encountered in temperate forests, where they are generally associated with the herbaceous layer (Byers \& Thornhill, 1983; Duelli, 2002). The fact that we caught so many in the upper layers could indicate a shift in their spatial niche within closed stands where the herbaceous and shrub layers are poorly developed, adults may turn to the canopy in order to forage. The high catches might also be a result of a strong attractiveness of the GMFTs. Mecoptera are known to be attracted to yellow traps, which are frequently used to catch them (e.g. Duelli et al., 2002; Mignon, 2002). The green colour of the GMFT mimics the colour of foliage and attracts several guilds of phyllophagous insects (Sallé et al., 2020), and might evoke a favourable hunting ground for Mecoptera.

All the species of Raphidioptera caught have bark-dwelling larvae, which can develop under the bark of oaks (Aspöck et al., 1980 in Hiermann et al., 2018; Aspöck, 2002; Alexander, 2004). They are recorded occurring in the canopy of pure or mixed oak stands in Europe and on oak branches (e.g. Barnard et al., 1986; Czechowska, 1997; Gruppe \& Schubert, 2001; Alexander, 2004; Gruppe et al., 2004; Gruppe, 2008; Weigelmeier \& Gruppe, 2010). Several species reported in previous surveys, such as Puncha ratzeburgi (Brauer), Venustoraphidia nigricollis (Albarda) and Dichrostigma flavipes (Stein), were not recorded during this study as they are restricted to Central Europe (Aspöck \& Aspöck, 2007). Conversely, surveys in Central Europe have never reported the presence of A. maculicollis, which is restricted to Western Europe (Aspöck \& Aspöck, 2007). The species recorded in this study are in accord with both the ecological preferences and known geographical distribution of the species. GMFTs were just as effective at catching adult Raphidioptera as Mecoptera. The green colour might be attractive for adults looking for aphids on

Table 3. Association between abundance and species richness of the different species of Mecoptera and Raphidioptera caught in oak canopies and the incidence of declining trees.

\begin{tabular}{|c|c|c|c|c|c|}
\hline & \multirow{2}{*}{$\begin{array}{c}\text { Variable }^{\dagger} \\
\text { (mean value per tree) }\end{array}$} & \multirow{2}{*}{ Best ecological model } & \multicolumn{3}{|c|}{ Effect of decline } \\
\hline & & & Estimate & SE & P-value \\
\hline \multirow{3}{*}{ Mecoptera } & Abundance $^{1}$ & Stand & -0.87 & 1.00 & 0.381 \\
\hline & Panorpa communis ${ }^{1}$ & Stand & -0.42 & 1.17 & 0.721 \\
\hline & Panorpa germanica ${ }^{1}$ & Stand & -1.14 & 1.21 & 0.347 \\
\hline \multirow{7}{*}{ Raphidioptera } & Abundance $^{1}$ & Plot & 2.07 & 0.63 & 0.001 \\
\hline & Species richness $^{1}$ & Stand & 1.29 & 0.51 & 0.011 \\
\hline & Subilla confinis ${ }^{1}$ & Plot & 3.51 & 0.91 & $<0.001$ \\
\hline & Phaeostigma major ${ }^{2}$ & Plot & 4.02 & 0.69 & $<0.001$ \\
\hline & Phaeostigma notata ${ }^{2}$ & Stand & 3.26 & 1.73 & 0.061 \\
\hline & Atlantoraphidia maculicollis ${ }^{2}$ & Tree & -1.20 & 0.63 & 0.057 \\
\hline & Xanthostigma xanthostigma ${ }^{2}$ & Tree & -0.77 & 0.45 & 0.092 \\
\hline
\end{tabular}

Generalized linear mixed-effects models fitted for a negative binomial ${ }^{1}$ or Poisson distribution ${ }^{2}$ with forest, stand, tree and trap type as random effects; ${ }^{\dagger}-$ the variable considered for species is abundance. Lines in bold indicate significant relationship between species abundance and decline level. 
foliage. However, the reason why we caught more males than females is unknown and apparently not previously reported.

Our results support the hypothesis that forest decline provides opportunities for colonization by species of both xylophagous and non-xylophagous saproxylic beetles (Sallé et al., 2020). Although there were not many species of Raphidioptera and they were not very abundant, markedly more were caught in declining trees, plots and stands. Duelli et al. (2019) report that most species of Neuroptera and Raphidioptera, including Phaeostigma notata, are more abundant in the years following a fire or wind throws. The abundance of larvae of Raphidioptera is positively correlated with arthropod abundance in their larval habitat (Weigelmeier \& Gruppe, 2010). The accumulation of dead branches in the canopy, with galleries and loose bark, probably provided a wider range of oviposition sites, larval habitats and suitable microclimates for $S$. confinis, $P$. major and $P$. notata. In addition, it could also have provided more prey for the larvae of these species, since declining trees or plots host more individuals, more biomass and more species of saproxylic insects (e.g. Sallé et al., 2020). However, the reduction in the density of foliage in the crowns of declining trees may result in a lower abundance of aphids and other Sternorrhyncha, which in turn may affect the abundance of adult Raphidioptera. This may explain why more A. maculicollis and X. xanthostigma tended to be caught by traps in healthy than in trees in decline. Their abundance, however, was quite low, and further sampling would be necessary to confirm this trend. Nevertheless, it indicates that these two species may have different ecological preferences compared to the species of Subilla and Phaeostigma and is in accord with the fact that they are active at different times each year (see below, Aspöck, 2002).

The abundance of Mecoptera was not associated with either tree or forest health. Mecoptera are presumably loosely dependent on trees for habitat and food since they have ground dwelling larvae and the adults are opportunistic feeders (Byers \& Thornill, 1983). Nonetheless, declineinduced defoliation can affect the microclimates in forests, within and below the canopy and so affect the understory and composition of the litter. This may in turn indirectly affect the communities dwelling in the herbaceous and shrub layers, as is reported for Mecoptera (Duelli et al., 2002), but not supported by our data.

Regarding seasonal activity, our observations indicate that $P$. germanica is bivoltine, as previously reported in Belgium and the Czech Republic (Meurisse \& Magis, 1989; Mignon, 2002; Vidlicka \& Holusa, 2007). Some authors also suggest that $P$. communis could have a facultative second generation in August (Meurisse \& Magis, 1989; Mignon, 2002), which was not detected in our study. We also did not record an earlier emergence of males, although it is apparently common in other species of Mecoptera (Byers $\&$ Thornill, 1983). As previously reported, there was a temporal shift in the main activity period of the two species of Mecoptera (Sauer 1970 in Meurisse \& Magis, 1989; Mignon, 2002; Vidlicka \& Holusa, 2007). The positively correlated abundances of these two species indicate they have similar habitat preferences, although they may exploit the vegetation in different layers (Sauer, 1973 in Byers \& Thornhill, 1983). As is suggested by Byers and Thornhill (1983), the temporal shift in the periods when they are active might result from a temporal segregation in order to avoid competition as species of Panorpa actively compete for food (Byers \& Thornhill, 1983; Thornhill, 1987). The species of Raphidioptera had two distinct seasonal patterns of activity, with an early peak for A. maculicollis and $X$. xanthostigma, and a slightly later peak for $S$. confinis, $P$. major and $P$. notata. This is in accord with previous observations for $P$. notata and $S$. confinis (Barnard et al., 1986; Duelli et al., 2002), but not those for X. xanthostigma and A. maculicollis (Alexander, 2004). Atlantoraphidia maculicollis overwinter as pupae, with adults emerging early in spring (Aspöck, 2002), as recorded in this study. The four other species overwinter as larvae, a short pupation occurs in spring and then the adults emerge in mid or late spring (Aspöck, 2002). This is also similar to our results for $S$. confinis, $P$. major and $P$. notata, but not in accord with the earlier activity of $X$. xanthostigma. As already mentioned, the abundance of the latter species was quite low and, therefore, seasonal activity recorded for this species needs to be confirmed. Since the abundances of $S$. confinis, $P$. major and $P$. notata are positively correlated with each other there is likely to be both a strong spatial and temporal overlap in their ecological niches.

\section{CONCLUSIONS}

Our study provides new data on canopy dwelling Mecoptera and Raphidioptera in temperate broadleaved forests in western Europe, two taxonomic groups that are largely understudied in that context. Our sampling proved to be efficient and is recommended for use in future studies on these insects. We demonstrate that some species of Raphidioptera prefer weakened and decaying plots and are promoted by forest decline.

ACKNOWLEDGEMENTS. This work was supported by Région Centre-Val de Loire Project no. 2018-00124136 (CANOPEE) coordinated by A. Sallé. We thank C. Moliard and G. Parmain (INRAE) and X. Pineau (University of Orléans) for their technical assistance. We are also grateful to the National Forestry Office (Office National des Forêts) and Forest Health Service (Département de la Santé des Forêts), with special thanks to S. Chevalier, A. Hachette, Y. Baugin, F. Mouy, H. Dézélut and Y. Deboisse for their field assistance. D. Fourcin edited the manuscript. Finally, we thank the two reviewers for their valuable comments.

\section{REFERENCES}

AleXANDER K.N.A. 2004: The larval habits of snakeflies (Raphidioptera: Raphidiidae). - Entomol. Record J. Variation 116: 113-114.

Allen C.D., Macalady A.K., Chenchouni H., Bachelet D., McDowell N., Vennetier M., Kitzberger T., Rigling A., Breshears D.D., Hogg E.H. et Al. 2010: A global overview of drought and heat-induced tree mortality reveals emerging climate change risks for forests. - For. Ecol. Manage. 259: 660-684. 
Aspöck H. 2002: The biology of Raphidioptera: a review of present knowledge. - Acta Zool. Acad. Sci. Hung. 48: 35-50.

Aspöck H. \& Aspöck U. 2007: The Raphidioptera of the Apennines Peninsula: a biogeographical analysis. - Ann. Mus. Civ. Stor. Nat. Ferrara 8: 95-106.

Aspöck H., Aspöck U. \& Hölzel H. 1980: Neuropteren Europas. Goecke \& Evers, Krefeld, 495 pp.

Barnard P.C., Brooks S.J. \& Stork N.E. 1986: The seasonality and distribution of Neuroptera, Raphidioptera and Mecoptera on oaks in Richmond Park, Surrey, as revealed by insecticide knock-down sampling. - J. Nat. Hist. 20: 1321-1331.

Bouget C. \& Duelli P. 2004: The effects of windthrow on forest insect communities: a literature review. - Biol. Conserv. 118: 281-299.

Byers G.W. \& Thornhill R. 1983: Biology of the Mecoptera. Annu. Rev. Entomol. 28: 203-228.

Connell J.H. 1978: Diversity in tropical rain forests and coral reefs. - Science 199: 1302-1310.

CzechowsKa W. 1997: A comparative analysis of the structure of Neuropteroidea communities of tree canopies in linden-oakhornbeam forests, light oak forests, mixed coniferous forests and pine forests. - Fragm. Faun. 40: 127-168.

Duelli P., Obrist M.K. \& Fluckiger P.F. 2002: Forest edges are biodiversity hotspots-also for Neuroptera. - Acta Zool. Acad. Sci. Hung. 48: 75-87.

Duelli P., Wermelinger B., Moretti M. \& Obrist M.K. 2019 Fire and windthrow in forests: winners and losers in Neuropterida and Mecoptera. - Alp. Entomol. 3: 39-50

Goudet M. \& Nageleisen L.M. 2019: Protocole Dépéris: Méthode de notation simplifiée de l'aspect du houppier des arbres forestiers dans un contexte de dépérissement. - For. Entrepr. 246: $36-40$

GRIME J.P. 1973: Competitive exclusion in herbaceous vegetation. Nature 242: 344-347.

GrupPe A. \& SCHUBERT H. 2001: The spatial distribution and plant specificity of Neuropterida in different forest sites in Southern Germany (Raphidioptera and Neuroptera). - Beitr. Entomol. 51: 517-527.

Gruppe A. \& SobeK S. 2011: Effect of tree species diversity on the neuropterid community in a deciduous forest. - Acta Entomol. Sloven. 19: 17-28.

Gruppe A., Gossner M. \& Simon U. 2004: Neuropteren in Wäldern Schwabens und Oberbayerns. - Beitr. Bayer. Entomofaunistik 6: 115-126.

Gruppe A., Gossner M., Engel K. \& Simon U. 2008: Vertical and horizontal distribution of arthropods in temperate forests. In Floren A. \& Schmidl J. (eds): Canopy Arthropod Research in Central Europe-Basic and Applied Studies from the High Frontier. Bioform, Nürnberg, pp. 383-405.

Hiermann U., Kopf T. \& Gruppe A. 2018: Nachweise von Kamelhalsfliegen (Insecta: Neuropterida: Raphidioptera) aus Vorarlberg und Nordtirol (Austria occ.), sowie Streudaten aus Europa. - Inatura - Fors. Online 55: $5 \mathrm{~S}, 5$ pp.

Houston D.R. 1981: Stress triggered tree diseases: the diebacks and declines. - USDA For. Serv. Rep. 41: 81, 36 pp.

IPCC 2013: IPCC, 2013: summary for policymakers. In Stocker T.F., Qin D., Plattner G.K. et al. (eds): Climate Change 2013: The Physical Science Basis. Cambridge University Press, Cambridge (UK) and New York (USA), pp. 3-32.

IshiI H.T., TANABE S.I. \& Hiura T. 2004: Exploring the relationships among canopy structure, stand productivity, and biodiversity of temperate forest ecosystems. - For. Sci. 50: 342-355.

Kenis M., Wermelinger B. \& GrégoIre J.C. 2007: Research on parasitoids and predators of Scolytidae - a review. In Lieutier F., Day K.R., Battisti A. \& Grégoire J.C. (eds): Bark and Wood
Boring Insects in Living Trees in Europe, a Synthesis. Springer, Dordrecht, pp. 237-290.

Liebhold A.M., Brockerhoff E.G., Kalisz S., NuÑez M.A., WarDLE D.A. \& WingfieLD M.J. 2017: Biological invasions in forest ecosystems. - Biol. Invasions 19: 3437-3458.

Magis N. \& Meurisse X. 1989: Précisions sur la phénologie des Panorpa Linné, 1758 de la faune de Belgique (Insecta: Mecoptera). - Bull. Ann. Soc. Roy. Belg. Entomol. 125: 265-272.

Manion P.D. 1981: Tree Disease Concepts. Prentice-Hall, Englewood Cliffs, NJ, 399 pp.

Mignon J. 2002: Evaluation de la diversité des Mécoptères d'un site de la région liégeoise (ru de Targnon, Theux, Belgique). Notes Fauniques Gembloux 46: 84-86.

Moretti M., Obrist M.K. \& Duelli P. 2004: Arthropod biodiversity after forest fires: winners and losers in the winter fire regime of the southern Alps. - Ecography 27: 173-186.

R Core Team 2018: R: A Language and Environment for Statistical Computing. R Foundation for Statistical Computing, Vienna. URL: https://www.R-project.org

Sallé A., Nageleisen L.M. \& Lieutier F. 2014: Bark and wood boring insects involved in oak declines in Europe: current knowledge and future prospects in a context of climate change. - For. Ecol. Manage. 328: 79-93.

Sallé A., Parmain G., Nusillard B., Pineau X., Brousse R., Fontaine-Guenel T., Ledet R., Vincent-Barbaroux C. \& Bouget C. 2020: Forest decline differentially affects trophic guilds of canopy-dwelling beetles. - Ann. For. Sci. 77: 86, 21 pp.

SAUER K.P. 1970: Zur Monotopbindung einheimischer Arten der Gattung Panorpa (Mecoptera) nach Untersuchungen im Freiland und im Laboratorium. - Zool. Jb. Abt. Syst. Geog. Biol. Tiere 97: 201-284.

SAUER K.P. 1973: Untersuchungen zur Habitatselektion bei $P a-$ norpa communis L. mit einem Beitrag zur Theorie des Begriffs Monotop und seiner Beziehung zur okologischen Nische. Zool. Jb. Abt. Syst. Geog. Biol. Tiere 100: 477-496.

Seidl R., Thom D., Kautz M., Martin-Benito D., Peltoniemi M., Vacchiano G., Wild J., Ascoli D., Petr M., Honkaniemi J. et AL. 2017: Forest disturbances under climate change. - Nat. Clim. Change 7: 395-402.

SÉmÉRIA Y. \& BERLAND L. 1988: Atlas des Névroptères de France et d'Europe: Mégaloptères, Raphidioptères, Névroptères Planipennes, Mécoptères. Boubée, Paris, 192 pp.

THORNHILL R. 1987: The relative importance of intra-and interspecific competition in scorpionfly mating systems. - Am. Nat. 130: 711-729.

TilLIER P. 2008: Contribution à l'étude des Mécoptères de France. Deuxième partie: clé de détermination des Panorpa de France (Mecoptera: Panorpidae). - Entomologiste 64: 21-30.

VIDLIČKA L. \& HolUŠA J. 2007: Neuroptera, Raphidioptera and Mecoptera assemblages inhabiting young spruce (Picea abies) forests: dominance structure and seasonal activity patterns. J. For. Sci. 53: 74-81.

Weigelmeier S. \& Gruppe A. 2010: Occurence of Raphidioptera larvae in dead wood of Quercus petraea (Matt.) Liebl. In Devetak D., Lipovšek S. \& Arnett A.E. (eds): Proceedings of the Tenth International Symposium on Neuropterology. Piran, Slovenia, June 22-25, 2008. Faculty of Natural Sciences and Mathematics, University of Maribor, Maribor, pp. 301-306.

WichmanN H.E. 1957: Untersuchungen an Ips typographus L. und seiner Umwelt: Die Kamelhalsfliegen. - Z. Angew. Entomol. 40: 433-440.

Received June 26, 2020; revised and accepted September 7, 2020 Published online October 6, 2020

Supplementary material follows (Table S1). 
Table S1. Number of individuals of each species of Raphidioptera and Mecoptera caught per tree and type of trap.

\begin{tabular}{|c|c|c|c|c|c|c|c|c|c|c|c|c|c|c|c|c|}
\hline \multirow{2}{*}{ Forest } & \multirow{2}{*}{$\begin{array}{c}\text { Stand } \\
\text { ID }\end{array}$} & \multirow{2}{*}{ Tree \# } & \multicolumn{2}{|c|}{ P. communis } & \multicolumn{2}{|c|}{ P. germanica } & \multicolumn{2}{|c|}{ P. major } & \multicolumn{2}{|c|}{ P. notata } & \multicolumn{2}{|c|}{ S. confinis } & \multicolumn{2}{|c|}{ X. xanthostigma } & \multicolumn{2}{|c|}{ A. maculicollis } \\
\hline & & & GMFT & $\overline{\text { FIT }}$ & GMFT & FIT & GMFT & FIT & GMFT & FIT & GMFT & FIT & GMFT & $\overline{\text { FIT }}$ & GMFT & FIT \\
\hline Marcenat & 12 & 1 & 62 & 1 & 331 & 2 & 1 & 1 & 0 & 0 & 12 & 0 & 0 & 0 & 0 & 0 \\
\hline Marcenat & 12 & 2 & 95 & 0 & 145 & 6 & 1 & 1 & 0 & 0 & 6 & 1 & 3 & 0 & 0 & 0 \\
\hline Marcenat & 37 & 1 & 129 & 0 & 382 & 1 & 0 & 0 & 0 & 0 & 0 & 0 & 1 & 0 & 0 & 0 \\
\hline Marcenat & 37 & 2 & 9 & 0 & 29 & 1 & 1 & 0 & 0 & 0 & 0 & 1 & 1 & 0 & 0 & 0 \\
\hline Marcenat & 58 & 1 & 39 & 0 & 77 & 0 & 0 & 0 & 0 & 0 & 5 & 0 & 7 & 0 & 0 & 0 \\
\hline Marcenat & 58 & 2 & 46 & 0 & 45 & 0 & 0 & 0 & 0 & 0 & 26 & 2 & 2 & 0 & 0 & 0 \\
\hline Orléans & 351 & 1 & 45 & 3 & 23 & 1 & 1 & 0 & 2 & 0 & 0 & 0 & 0 & 0 & 1 & 0 \\
\hline Orléans & 351 & 2 & 179 & 8 & 57 & 0 & 1 & 0 & 0 & 0 & 0 & 0 & 0 & 0 & 0 & 0 \\
\hline Orléans & 751 & 1 & 11 & 1 & 22 & 0 & 0 & 0 & 0 & 0 & 0 & 0 & 1 & 0 & 3 & 0 \\
\hline Orléans & 751 & 2 & 0 & 0 & 17 & 0 & 0 & 0 & 0 & 0 & 0 & 0 & 1 & 0 & 11 & 0 \\
\hline Orléans & 1140 & 1 & 0 & 0 & 7 & 0 & 2 & 0 & 2 & 1 & 7 & 0 & 0 & 0 & 0 & 0 \\
\hline Orléans & 1140 & 2 & 0 & 0 & 1 & 0 & 0 & 0 & 0 & 1 & 6 & 0 & 0 & 0 & 0 & 1 \\
\hline Orléans & 1343 & 1 & 31 & 0 & 138 & 0 & 0 & 0 & 2 & 0 & 1 & 0 & 0 & 0 & 0 & 0 \\
\hline Orléans & 1343 & 2 & 18 & 5 & 56 & 11 & 1 & 0 & 0 & 0 & 0 & 0 & 0 & 0 & 4 & 0 \\
\hline Orléans & 1346 & 1 & 13 & 1 & 92 & 3 & 0 & 0 & 1 & 0 & 2 & 0 & 1 & 0 & 0 & 0 \\
\hline Orléans & 1346 & 2 & 15 & 1 & 29 & 1 & 0 & 0 & 0 & 0 & 0 & 0 & 0 & 0 & 0 & 0 \\
\hline Orléans & 1427 & 1 & 16 & 2 & 31 & 2 & 1 & 0 & 5 & 0 & 15 & 1 & 1 & 0 & 6 & 0 \\
\hline Orléans & 1427 & 2 & 25 & 0 & 60 & 3 & 0 & 0 & 1 & 0 & 2 & 0 & 1 & 0 & 3 & 1 \\
\hline Orléans & 1490 & 1 & 99 & 12 & 172 & 9 & 0 & 0 & 0 & 0 & 0 & 0 & 0 & 0 & 0 & 0 \\
\hline Orléans & 1490 & 2 & 10 & 0 & 23 & 0 & 0 & 0 & 0 & 0 & 0 & 0 & 0 & 0 & 0 & 0 \\
\hline Orléans & 1491 & 1 & 20 & 0 & 100 & 2 & 0 & 0 & 0 & 0 & 0 & 0 & 0 & 0 & 1 & 0 \\
\hline Orléans & 1491 & 2 & 60 & 0 & 319 & 1 & 0 & 0 & 0 & 0 & 0 & 0 & 2 & 0 & 0 & 0 \\
\hline Orléans & 1502 & 1 & 140 & 4 & 96 & 2 & 1 & 0 & 0 & 0 & 4 & 0 & 0 & 0 & 1 & 0 \\
\hline Orléans & 1502 & 2 & 97 & 2 & 139 & 0 & 0 & 0 & 0 & 0 & 0 & 0 & 0 & 0 & 0 & 0 \\
\hline Vierzon & 19 & 1 & 36 & 1 & 50 & 0 & 0 & 0 & 0 & 0 & 0 & 0 & 0 & 0 & 2 & 0 \\
\hline Vierzon & 19 & 2 & 28 & 1 & 14 & 0 & 0 & 0 & 1 & 0 & 0 & 0 & 3 & 0 & 2 & 0 \\
\hline Vierzon & 35 & 1 & 13 & 0 & 19 & 0 & 0 & 0 & 1 & 0 & 1 & 0 & 0 & 0 & 6 & 0 \\
\hline Vierzon & 35 & 2 & 54 & 3 & 65 & 0 & 0 & 0 & 0 & 0 & 0 & 1 & 1 & 0 & 2 & 0 \\
\hline Vierzon & 70 & 1 & 57 & 1 & 40 & 0 & 5 & 2 & 9 & 0 & 8 & 1 & 5 & 0 & 1 & 1 \\
\hline Vierzon & 70 & 2 & 32 & 0 & 14 & 0 & 32 & 1 & 11 & 0 & 102 & 0 & 0 & 0 & 1 & 0 \\
\hline Vierzon & 71 & 1 & 137 & 2 & 99 & 3 & 2 & 2 & 1 & 0 & 2 & 0 & 2 & 0 & 1 & 0 \\
\hline Vierzon & 71 & 2 & 309 & 5 & 118 & 0 & 31 & 1 & 2 & 0 & 56 & 3 & 5 & 0 & 0 & 0 \\
\hline Vierzon & 81 & 1 & 14 & 1 & 15 & 0 & 0 & 1 & 1 & 0 & 5 & 0 & 0 & 0 & 0 & 0 \\
\hline Vierzon & 81 & 2 & 26 & 1 & 63 & 0 & 2 & 0 & 0 & 0 & 4 & 0 & 1 & 0 & 1 & 0 \\
\hline Vierzon & 179 & 1 & 34 & 1 & 2 & 0 & 0 & 0 & 19 & 0 & 4 & 4 & 1 & 1 & 4 & 0 \\
\hline Vierzon & 179 & 2 & 52 & 2 & 9 & 0 & 2 & 1 & 5 & 0 & 25 & 0 & 0 & 0 & 0 & 0 \\
\hline Vierzon & 236 & 1 & 2 & 0 & 2 & 0 & 0 & 0 & 0 & 0 & 0 & 0 & 0 & 0 & 0 & 0 \\
\hline Vierzon & 236 & 2 & 44 & 4 & 14 & 0 & 1 & 0 & 1 & 0 & 0 & 0 & 1 & 0 & 0 & 0 \\
\hline Vierzon & 249 & 1 & 115 & 1 & 54 & 0 & 0 & 0 & 0 & 0 & 0 & 0 & 1 & 0 & 0 & 0 \\
\hline Vierzon & 249 & 2 & 86 & 1 & 39 & 1 & 0 & 0 & 0 & 0 & 1 & 0 & 0 & 0 & 1 & 0 \\
\hline Vierzon & 290 & 1 & 17 & 0 & 4 & 0 & 0 & 0 & 0 & 0 & 1 & 0 & 2 & 0 & 0 & 0 \\
\hline Vierzon & 290 & 2 & 23 & 0 & 11 & 0 & 0 & 0 & 0 & 0 & 1 & 0 & 3 & 0 & 0 & 0 \\
\hline Total & & & 2238 & 64 & 3023 & 49 & 85 & 10 & 64 & 2 & 296 & 14 & 46 & 1 & 51 & 3 \\
\hline
\end{tabular}

